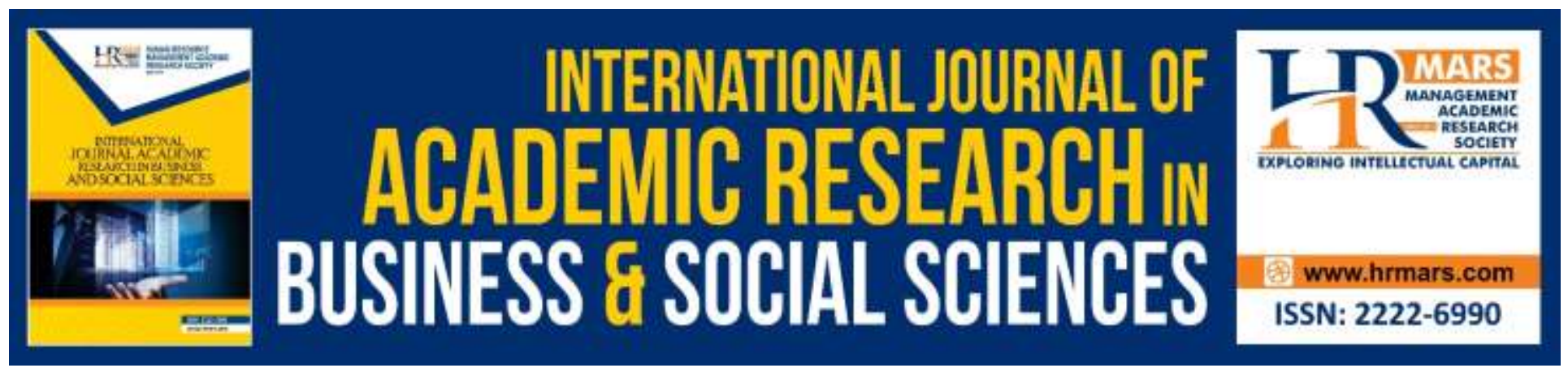

\title{
Using Songs to Reduce Language Anxiety in Speaking English in ESL Classroom
}

\author{
Irina Emmanuella Anak Ejeng, Harwati Hashim, SK Sungai Duan
}

To Link this Article: http://dx.doi.org/10.6007/IJARBSS/v10-i2/6917

DOI:10.6007/IJARBSS/v10-i2/6917

Received: 29 December 2019, Revised: 08 January 2020, Accepted: 30 January 2020

Published Online: 09 February 2020

In-Text Citation: (Ejeng et al., 2020)

To Cite this Article: Ejeng, I. E. A., Hashim, H., \& Duan, S. S. (2020). Using Songs to Reduce Language Anxiety in Speaking English in ESL Classroom. International Journal of Academic Research in Business and Social Sciences, 10(2), 151-165.

Copyright: (c) 2020 The Author(s)

Published by Human Resource Management Academic Research Society (www.hrmars.com)

This article is published under the Creative Commons Attribution (CC BY 4.0) license. Anyone may reproduce, distribute, translate and create derivative works of this article (for both commercial and non-commercial purposes), subject to full attribution to the original publication and authors. The full terms of this license may be seen

at: $\underline{\text { http://creativecommons.org/licences/by/4.0/legalcode }}$

Vol. 10, No. 2, 2020, Pg. 151 - 165

http://hrmars.com/index.php/pages/detail/IJARBSS

JOURNAL HOMEPAGE

Full Terms \& Conditions of access and use can be found at http://hrmars.com/index.php/pages/detail/publication-ethics 


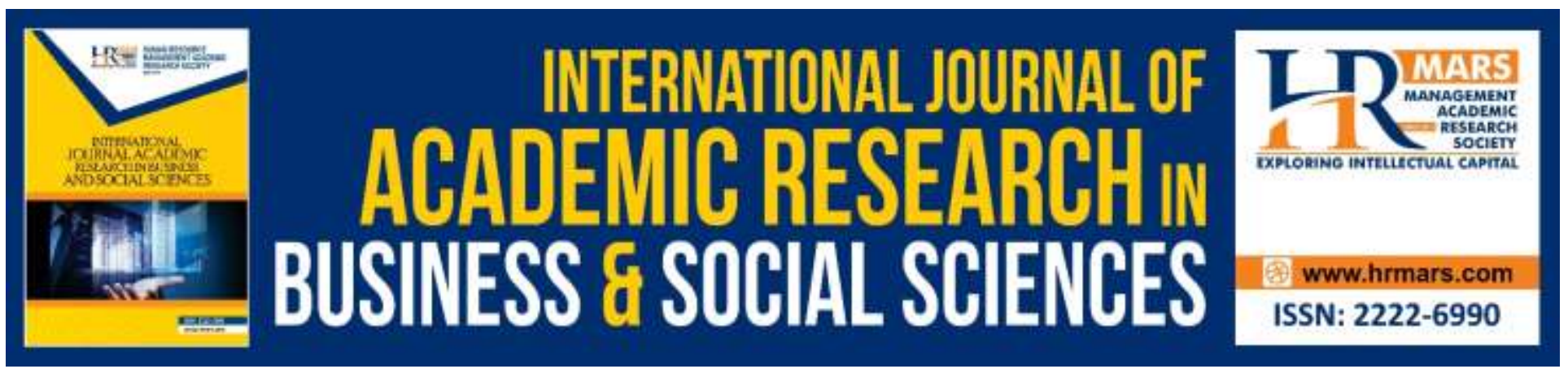

\title{
Using Songs to Reduce Language Anxiety in Speaking English in ESL Classroom
}

\author{
Irina Emmanuella anak Ejeng, Harwati Hashim, SK Sungai Duan
}

Faculty of Education, Universiti Kebangsaan Malaysia (UKM), 43600 Bangi, Selangor, Malaysia. 2

\section{Abstract}

English proficiency is very important. Our Ministry of Education have been emphasizing about the importance of English language. They introduced various methods to help our young learners. Young learners love to do something fun and involving action.Among the four skills in learning English, Speaking is one of the most crucial skill. Anxiety in speaking English language is the major factor why pupils are reluctant to participate in oral activities. They are scared of making mistakes and eventually become not self-confidence to speak in English. Their anxiety of speaking English makes them cannot excel in English and forever appalled of using English to communicate. The anxiety to make mistakes makes them demotivated to use the language. Young learners with low motivation usually are reluctant to speak in the target language. The growing needs of English language increased the roles of this language in society today. Realizing the increasing needs, the education system in Malaysia is built to equip young Malaysians to compete in the $21^{\text {st }}$ century. In Malaysia, English is taught as a second language. Students are required to receive eleven years of formal education in both primary and secondary school.

Undoubtedly, the most effective teaching method to teach English in ESL classroom is among the major issue to be discussed in Malaysia Education System. Songs help to motivate them and boost their confidence. Songs has been a part of every level of society and cultures. It can be fun and engaging to the learners. Not only that using songs able to support language focus and increase the attention span of the learners. Young learners are usually more attracted in the use of songs in their lesson since they are still very much attracted to activity that involves total physical response.

Keywords: Anxiety, English, Motivation, Songs, ESL Classroom

\section{Introduction}

Malaysia is a unique country because of the diversity of the cultures, religion and ethnicity. The linguistics situation in Malaysia is pretty much a result of its multiracial status. The main races in Malaysia are Malay, Chinese, Indian and Bumiputera Sabah Sarawak. There are different dialects in every state in Malaysia and that contributes to the diverse linguistic situation. This exquisite language phenomenon is because of the multi- races in the country. Most Malaysian are capable of speaking Malay and English, these two languages are used widely and regularly in their daily conversation. 
Unfortunately, English is definitely not a common second language for Malaysian, their first language is usually their mother tongue and second language is the national language Bahasa Malaysia. Many first-time learners have to face difficulties in learning second language because they are not confident in using the language. Learning English causes, them to feel anxiety. Anxiety is a form of feelings that causes someone to worry a lot and decrease their motivational level. Second language or foreign language speaking anxiety have sparked a lot of attention in the recent years. It is very important to reckon the source of anxiety among the primary school pupils. Anxiety is one of the causes of having difficulties in language learning as it reduces learners' motivation in using the language. Their lack motivation to speak the language causes their lack of proficiency in speaking the language learn. They will become shy to acquire the knowledge or language skill just because of their high anxiety level and low motivation. Delinquent to that understanding, many studies have been carried out to identify the factors that contribute to the feeling of anxiety among pupils in English Language. Unfortunately, most studies seem to focus more on learners from secondary and also tertiary levels learners. Less researchers are doing research on the primary school levels.

\section{The Research Problem}

This paper is going to elaborate more about the factors that affects the motivation of the second language learners in primary school to speak English and also the method use to assist them. This paper discusses the anxiety of ESL (English as Second Language) learners to speak in English language. In Malaysia, English is one of the crucial subjects. The students have to acquire all the four skills in learning English. The skills are listening, speaking, reading and writing but speaking is the most important skill. Speaking skills are crucial especially because it can also affect other skills of students. Students needs to be able to interact in English to survive in the massive development of profession in the country that requires them to be able to communicate using English.

Speaking in English is very important in term of communicative ability and for students to interact with other English users. Unfortunately, some students develop anxiety and lack of motivation whenever they are required to speak in English. Language anxiety causes their motivation to decrease and their interest to study the language become decrease. Therefore, it is appropriate to investigate and examine students' perceptions towards the anxiety in learning English.

\section{Purpose of the Study}

In order to identify language learning in the Malaysian school context, we should explore the factors that contribute to the way in which English education is conducted in Malaysia. Students' motivation and interests in the language class can determine their level of anxiety, as well as promote or hinder their language learning performances. The paper tries to identify the factors of anxiety and motivation of lower secondary students towards learning English Language. Language anxiety is the major factor in affecting the speaking skill of students and this result in their weakness and lack of motivation to use English as a medium of communication during formal and also informal situation. The serious effects of this problems towards the learning of students leads to the need to conduct this research. This research also specifies to use songs to help reduce the pupil's anxiety in speaking English language. 
INTERNATIONAL JOURNAL OF ACADEMIC RESEARCH IN BUSINESS AND SOCIAL SCIENCES

Vol. 10, No. 2, Feb, 2020, E-ISSN: 2222-6990 @ 2020 HRMARS

\section{Research Questions}

In this study the following questions guided my research:

a) What are the factors causing students anxiety to speak in English?

b) Why students feel anxiety to speak in English?

c) How songs can facilitate in reducing language anxiety among students?

d) Why song can be used as a tool to reduce language anxiety among students?

\section{Literature Review}

There are various researchers that have conducted research about the use of songs to motivate pupils to speak English. Malaysia is one of many countries that accepted English as their second language. A vast amount of research has also been conducted to identify the factors contributing to language anxiety among learners. In Malaysian primary school, most of the pupils are merely demotivated to speak English.

They are scared of making mistakes and they have anxiety towards the usage of the language. According to Walker (2006), the usage of songs in a classroom will increase the usage of English. It is not only a powerful technique to teach English but also motivate the pupils to love the language. Using songs may assist in teaching young learners. So, the use of songs and games is an effective tool in teaching English for young learners especially if it made them unconscious that they are learning a language. The usage of songs will increase the interesting and enjoyable environment for learning and lessening the burden of anxiety.

English Language is known as a Lingua Franca or medium of communication among foreign countries. English language becomes a common means for speakers of different first languages. English has removed the language barriers between different countries and this increase the development of various countries. Unfortunately, in Malaysia most English as Second Language learners have anxiety to speak in English.

Language anxiety is a feeling of being afraid to make mistakes and being judge by others. Choy and Troudi (2006) stated in their research that half of their respondents reported feeling afraid and reluctant to speak English. The fear arises due to their anxiety of making mistakes while using the spoken language. The respondent also feels very distressed about being corrected by others.

Suleimenova (2013) noted that the concern over communication competence among second or foreign language learners in the recent years may trigger a high level of speaking anxiety. In his study, the foreign language learners stated that they feel stressful, nervous and anxious while learning to speak using the target language and said to have 'mental block' against language learning.

This shows that language anxiety actually affects the motivation of English as Second Language learners to communicate in that language. They become stressful because of the anxiety and it causes them to be unable to speak clearly and their word choices become limited because of the anxiety. According to Pourhosein Gilakjani, Leong, and Saburi (2012), desire or the extent to which a person try to get their goal determine the success. If people are not motivated to do something, they will not put effort in learning the language. The same thing applies in this situation in which the ESL learners are not motivated to speaks in English. In general people refer to this psychological factor as motivation, a motive force that arouses, incites, or stimulates action. Motivation is an important factor in specifying the readiness of learners to communicate. Communications requires the communicator to be ready and confident. 
INTERNATIONAL JOURNAL OF ACADEMIC RESEARCH IN BUSINESS AND SOCIAL SCIENCES Vol. 10, No. 2, Feb, 2020, E-ISSN: 2222-6990 @ 2020 HRMARS

A few researchers also agree with the research that motivation affects learners' desire to learn the language. Al-Otaibi (2004) stated that a motivated learner spends much of their time to gain aims in learning second or foreign language. He also mentions that a motivated learner can also learn language more effectively than unmotivated ones. Al-Hazemi (2000) supported his statements by saying that learners with strong desire to learn a language can obtain high level of competence in the target language.

Lucas (2010) said that learners are intrinsically motivated to learn speaking and reading skills. He also stated that learners are also intrinsically motivated through knowledge and achievement. Learners' with higher level of motivation will definitely more motivated to speak in English. According to Murphey (1990), songs are particularly beneficial to language acquisition because they trigger more effectively. Songs are repetitive and the melody itself are very catchy, learners can learn through the lyrics to apply in real life situations. Some song lyrics also increases motivation because learners can relate the lyrics to their situations in life.

\section{Songs in English Language Learning}

In most Asian countries, English is not the citizens' first language. Most of the English speakers usually learn English as second language in school. Most of them are usually exposed to English via songs and also broadcast in television. Otillie (2010) stated that these people first exposure to the English language is probably through listening to popular songs. Lynch (2005) expressed in his article that English language teachers should use songs as a component part of their teaching. Songs are also easily obtainable and fun to listen to plus it is repetitive. The utilization of songs in teaching language can also display assortment and differentiation because songs can function as an instrument to pioneer diverse new vocabulary. Moreover, songs can be used to expose people to cultural aspects and familiarize them to different types of English accents. Lynch (2005) also stated in his article that songs can be designated to adhere to the multiple needs and interests of students. The lyrics itself can be used to colligate to real life situations, struggles and various issues happening around the world. Generally, songs can substance pleasurable speaking, vocabulary and language drill while enjoying the rhythm and melody.

Orlova (2003) claims students are put at ease when the song is used in the classroom. In her 10year experience of using songs in the language teaching, she claims that her students are more interested in the lesson and their desire to learn a language is increase. Music offers a versatile way to look at language and students will not feel the burden of learning the language. It can also be a very effective tool to reinforce and improve speaking, listening comprehension, vocabulary and language in general. In 2010, Beare wrote an article on using music for the ESL (English as Second language) classroom that supported Orlova 's statements. According to him, using music in the beginning of a lesson is a great way to introduce new vocabularies to students. It can also lead them to thinking in the right direction to guide them and give them the gist about what they are learning and overall ideas about what the lesson is about.

Lo and Li (1998) also suggested that songs can provide a break from the normal classroom routine and the learning of English through the use of songs will develop a non-threatening environment classroom environment. When the students are comfortable with the atmosphere in the classroom, then the four language skills can be enhanced. 
INTERNATIONAL JOURNAL OF ACADEMIC RESEARCH IN BUSINESS AND SOCIAL SCIENCES Vol. 10, No. 2, Feb, 2020, E-ISSN: 2222-6990 @ 2020 HRMARS

\section{Language Anxiety}

Language anxiety is actually one of the main factors that needs to be considered in learning a language. It can affect the learning and also teaching of second language massively because in learning a language, the learners are requiring to speak the language. According to Brown (2001) defined language anxiety as the feelings of uneasiness, worry, nervousness, self-doubt, frustration and apprehension that a non - native speakers experienced when learning or using a second language. These non - native speakers will feel anxious and panic when they need to use the English language. Each learner is believing to respond differently to language anxiety. Language anxiety may affect a student positively and also negatively. The students that are affect positively will tend to find various ways to overcome their anxiety meanwhile those who have been affected negatively usually tend to avoid anxiety in learning the language. This will lead to their poor performance and also refusal to communicate in English.

Ellis (2008) list out some indication of a language anxiety such as the lack of confidence, unwilling to speak in the target language and sometimes even experiencing insomnia when they are needed to communicate in public. The most common cases are when the non- native speakers have to give oral presentation. There are two types of anxiety according to Woodrow (2006), there are in - class anxiety and also out of class anxiety. Extrinsic factors such as social and also cultural surroundings also end kindle anxiety. For example, a non - native speakers are usually conscious and precarious about other peoples' opinion whenever they commit mistakes.

Language anxiety affects the pupils' motivation level to speak the language. Their fright of making mistakes and judgement from others causes them to stop communicating in English. Sometimes people are not judging them but they themselves have the insecurities because of their lack of confidence.

Using songs is one of a very significant tools that can reduce their anxiety and also increases their motivation level. Song are very fun and also catchy. Some songs also have meaningful lyrics and also since it is repetitive, the listeners are usually able to mouth the lyrics and sometimes sing along to songs. Some songs itself are about motivation and the listeners can usually relate to the lyrics. The learner's motivation level increases and they are less anxiety, speaking the language will not be a big issue or concern for the learners. Speaking English is all about self-assurance because the intention of speaking is just to ensure other people be able to comprehend the message you are trying to deliver and get the main contents of what you are trying to tell them.

According to Setia et al. (2012) songs is effective in creating positive attitude and motivation in primary school ESL learners in Malaysia. The results indicated that "the use of song not only helps the understanding, it also stimulates and increases the students' interest to learn, enjoy and engage in the learning process" (p. 270). When the learners are interested to learn, their motivation level will be higher and obviously will affect their anxiety. The learners will be less anxiety and their reluctance to use the language will be lower. The results also suggest that songs have a positive outcome on the learners' self-confidence and theoretical success by supplying more laid-back and favorable learning surroundings. Peacock (1997) also mention that songs can be beneficial to language teaching by improving learners' motivation, which is fundamental to a successful learning process. The language learners' motivation can be increased significantly through the employment of authentic materials such as various genre of songs. 
The use of songs boosts learners' motivation to speak in the target language. On the other hand, when the motivation level is higher, they will no longer have anxiety to speak in English. Songs usually have repetitive lyrics so the learners will also be able to learn new vocabulary that they can use the new words whenever they are speaking the language in real life situations and also implement the new vocabularies in their language learning class.

\section{Methodology \\ Research Design}

This research is conducted in a school situated in a rural area in Mukah. It is a mixed abilities school.The medium of instruction of the school are Bahasa Malaysia and English. Most of the pupils' first language is Iban. They mostly communicate using Iban with their friends and only communicate using the target language in class. This research main purpose are to investigate the anxiety level of students in using English language as the medium of instruction and also the factors that are affecting their reluctance to communicate in English.

The research will be a qualitative research. Qualitative research was chosen as the research design because this study aims to know the factors that causes pupils' anxiety in speaking English and find out the effectiveness of using songs to reduce the anxiety. Ary et al (2010) expressed that the aim of qualitative research is to understand a phenomenon in general and to know the phenomenon in depth of understanding the data analysis. In a qualitative research, researcher can ask specific questions to the participants to explore more about the phenomenon to get more information. One of the varieties in qualitative research is basic interpretative study. Researchers usually use interviews and also observation to collect data to understand the participants experience and point of view. This research main point is to know in general and also deeply the language anxiety phenomenon among pupils. Their inabilities and also anxieties to use English in class and also outside of the class.

\section{Research Sample}

In this research, there are 30 pupils that have been chosen as the samples. They are pupils from Year 4 class in a government school in rural area in Mukah, Sarawak. It is located in a place with limited facilities such as internet connections and also electricity. The pupils' native language is mostly Iban. They are from mixed abilities and also their first language is Malay since its their medium of instructions in school.

\section{Data Collection (Instruments)}

Three instruments have been utilizing for the data collection method in this research. This research is a qualitative research and the instruments use are journal writing, questionnaire and semi-structured interview. The data collected was then analyzed, the questionnaire data are analyzed using simple frequency count and the answers from the interviews are arrange and collected in distinguishing the students language anxiety in using English language as a medium of instruction and whether the use of songs are help to reduce their anxiety to speak English in an ESL classroom.

\section{Questionnaire}

The first instrument use is questionnaire. The purpose of using questionnaire in this research is to find out when do the pupils feel more anxious in using the target language and what causes their 
anxiety. The researcher will observe the participants before and after the use of songs to see the different of attitude they have towards speaking in the target language.

Questionnaire help researcher to collect extensive data in a very limited time. It can be used to research almost any aspect of teaching and learning. Key (1997) stated that a questionnaire is a mean of eliciting the feelings, beliefs, experiences, perceptions or attitudes of some sample of individuals.

The questionnaire was design to find out what causes the massive or main reason to pupils' anxiety to communicate in English and whether the use of songs help in reducing their anxiety to communicate.

The questionnaire items were developed to find out the reason and also factors that causes anxiety in speaking English. The questionnaire was administered to all the participants before the lesson to find out the cause of their language anxiety. Each item was explained first to the pupils to ensure they understand better about the questionnaire. The time allocated to answer the questionnaire was abundant and the items were simple and easy to comprehend.

\section{Interview}

The interview will be a semi structured interview. Interview is the most crucial data collection tool in a qualitative research. It is a good way of approach people's perceptions, meanings, definition and constructions of reality (Punch, 2009). Interview is one of the popular instruments use in a qualitative research. It is a process in which the researchers ask the participant an open-ended question and record the answers.

According to Mc Namara (1999) interview are peculiarly useful for investigating profoundly into the learners' occurrence. It can also help pursuing in-depth and specifically about a topic. It can also be helpful as a follow up with the participants react after a questionnaire to further look into the rational motive between their decision making.

\section{Journal Writing}

Journal writing is an important tool to help someone to reflect and improve in their learning process. Journal writing is another instrument that is implemented in this research.

The participant writes their reflection and point of view about what they feel before and after the lesson using songs. The participant also reflects on the reason why they feel anxious to communicate in English.

Wallace (1999) stated that journals were the shared accounts of personal's actions, thoughts and feelings written by the person himself and herself usually on daily basis. Therefore, journal writing can help researcher to understand more about the participant feelings and also thoughts. The journal entries will be useful for researcher to get to know in deep about how the participants feels and why anxiety occurs whenever they need to speak in the target language.

\section{Data Collection Interview}

In this research, two types of interview sessions were conducted. The first interview was conducted to find out participants level of anxiety and what is the main cause of their anxiety. The second interview was conducted after using songs and to observe the effectiveness of using song to reduce language anxiety to communicate in the target language. These interviews were conducted 
INTERNATIONAL JOURNAL OF ACADEMIC RESEARCH IN BUSINESS AND SOCIAL SCIENCES

Vol. 10, No. 2, Feb, 2020, E-ISSN: 2222-6990 @ 2020 HRMARS

to find out the differences in the pupil's reaction and also motivation to speak in the target language after the use of songs.

Example of the first interview questions are;

1. How do you feel when you have to communicate in English?

2. Why are you afraid to speak in English?

3. Is English important to you? Why?

4. What makes you afraid to speak English with others?

The responses from the interview were then analyse to find out the reason why the participants are reluctant and feel anxiety to speak in English. The following were some of the responses from the participants to the questions.

Question: Is English important to you?

Pupil A: Yes, but I cannot speak English very good.

Pupil B: Yes, can understand movie.

Pupil C: Yes, because English is important subject.

Pupil D: Yes, because can speak with 'orang putih (foreigners).

Pupil G: Yes, because I can understand English songs.

These responses show that the pupils are aware and knows the importance of using English in everyday life. They know that English is one of the crucial subjects and they need to master English. They also know that using English will enable them to communicate with foreigners and socialise with others.

Question: What makes you afraid to speak English with others?

Pupil A: I am afraid that my friend will laugh at me.

Pupil B: I 'salah sebut' the words and my friend 'kutuk' me. (I pronounce some words incorrectly and my friend judge me)

Pupil E: I nervous speak in front of people.

Pupil F: I afraid because my friend laughs and look at me.

Pupil H: I am afraid that teacher will angry at me.

Pupil Y: I am scared and cannot speak.

From these responses, we can see that most of the pupils are willing to communicate in English but they are afraid of making mistakes and become the laughing stock of their friends. Some of the pupils also feels anxious whenever they have to speak in front of their friends especially in English because they are not familiar with the usage of English in everyday life. The pupils also tend to become so afraid that they were unable to speak. Most of the responses from the interviews were the same, the pupils become demotivated if they make mistakes for example mispronounce certain words.

Question: How do you feel when you have to speak in English? Why?

Pupil E: Scared because friend can see me.

Pupil F: Nervous, want to cry because afraid. 
INTERNATIONAL JOURNAL OF ACADEMIC RESEARCH IN BUSINESS AND SOCIAL SCIENCES

Vol. 10, No. 2, Feb, 2020, E-ISSN: 2222-6990 @ 2020 HRMARS

Pupil A: I feel afraid because if I say the words wrongly, people laugh.

Pupil Z: I cannot speak loud, afraid say the word wrong.

The responses above shows that these pupils are anxious and scared to speak English because they are afraid of peoples' judgement when the speak the words wrongly. Most of the pupils tend to become demotivated to speak because they are scared of saying the words wrong and not knowing the correct vocabulary to use. The next interview result was conducted after using songs in the lesson.

Question: How do you feel about today's lesson?

Pupil A: I have fun, not afraid to speak English.

Pupil B: I am happy, we sing together.

Pupil C: I am not afraid to speak English because we sing together then speak.

Pupil E: I learn how to pronounce the words by listening to the song. I am happy not afraid.

The pupils feel happier when songs are implemented in the lesson. It makes them feel more comfortable to communicate in English and they are less anxious to speak because they are obviously enjoying themselves. Songs have a tendency to attract people's interest because of the catchy rhythm and also music.

Question: Are you afraid to speak English?

Pupil B: No, I enjoy because I can sing with my friend and speak using the lyrics.

Pupil E: No, I can pronounce the words after singing the song.

Pupil F: No, I am not afraid because we do activity together, If wrong,wrong together.

Pupil Z: I can sing loudly the lyrics because I know how to say the words.

Pupil A: I am not afraid because if I know how to pronounce the words.

These shows that by implementing songs in the lesson increases their motivation to communicate in the target language. They are more confident and not afraid to make mistakes because they feel that their friends also make the same mistakes. They are more confident to communicate in English because they know how to pronounce certain words after listening to the song.

\section{Journal Writing}

Some participants were picked to write their journal entries. The participants were picked based on the highest level of anxiety based on the data from their questionnaire. These participants shared their thoughts and feelings about the reason why their feel anxiety. Some participant wrote their journal entries in Some of the examples are as follows;

I am scared to speak in English. I am shy when I make mistake and my friend laugh at me.English is hard and not fun.

Journal Entry 1

My friend always laugh at me when I speak English. I don't know how to say the word. I want to speak English but scared. 


\section{Entry 2}

These are a few journal entries that shows most of the pupils were scared to communicate in English because they are scared of their friends' responses. It is mostly because of peer pressure. Some of the pupils also shows different thoughts about the reason they feel language anxiety whenever they need to communicate in English.

I can speak English but sometimes I use the wrong word and people cannot understand me. I become nervous when I have to speak in front of everyone.

Journal Entry 3

I cannot speak English in front of many people. I become nervous and forget the words when I look at them.

\section{Journal Entry 4}

I am scared that my teacher will get angry at me so I do not want to try to speak in English. I become nervous especially of many people hear me speak.

\section{Journal Entry 5}

From these journal entries, it is pretty obvious that these participants feel nervous whenever they have to use English language in front of many people. They are scared of making mistakes and these discourage them to even try to communicate in English.

\section{Questionnaire}

The questionnaire questions are mostly related to the various reasons of why pupils become anxious to speak in the target language. The frequency of the answers has been calculated to shows the major factors that contributes to language anxiety.

There are four choices in the questionnaire, 1 strongly agree, 2 agree, 3 disagree and 4 strongly disagree. The participants will tick the box that they feel they must agree with. The researcher explains to the participants about each question to ensure that they understand better about which answer to pick. 
INTERNATIONAL JOURNAL OF ACADEMIC RESEARCH IN BUSINESS AND SOCIAL SCIENCES Vol. 10, No. 2, Feb, 2020, E-ISSN: 2222-6990 @ 2020 HRMARS

\begin{tabular}{|l|l|l|l|l|l|}
\hline No & Questions & $\begin{array}{l}\text { Strongly } \\
\text { agree }\end{array}$ & Agree & Disagree & $\begin{array}{l}\text { Strongly } \\
\text { disagree }\end{array}$ \\
\hline 1 & $\begin{array}{l}\text { I feel scared when I } \\
\text { speak in English. }\end{array}$ & & & & \\
\hline 2 & $\begin{array}{l}\text { I am afraid to speak in } \\
\text { English. }\end{array}$ & & & & \\
\hline 3 & $\begin{array}{l}\text { I am scared to speak } \\
\text { English in public. }\end{array}$ & & & & \\
\hline 4 & $\begin{array}{l}\text { My friend always } \\
\text { laughs when I make } \\
\text { mistakes. }\end{array}$ & & & & \\
\hline 5 & $\begin{array}{l}\text { I do not understand } \\
\text { English. }\end{array}$ & & & & \\
\hline 6 & $\begin{array}{l}\text { I cannot pronounce } \\
\text { English words. }\end{array}$ & & & & \\
\hline 7 & $\begin{array}{l}\text { I am confused with } \\
\text { some words in English. }\end{array}$ & & & & \\
\hline 8 & I do not like English. & & & & \\
\hline 9 & $\begin{array}{l}\text { I am nervous to speak } \\
\text { English with my friend. }\end{array}$ & & & & \\
\hline 10 & $\begin{array}{l}\text { I am scared to use } \\
\text { English. }\end{array}$ & & & & \\
\hline
\end{tabular}

The data from the pupils were collected and then the frequency was counted. The data were as follows; the numbers are the total participants that picked each stand.

\begin{tabular}{|c|c|c|c|c|c|}
\hline No & Questions & $\begin{array}{l}\text { Strongly } \\
\text { agree }\end{array}$ & Agree & Disagree & $\begin{array}{l}\text { Strongly } \\
\text { disagree }\end{array}$ \\
\hline 1 & $\begin{array}{l}\text { I feel scared when I speak in } \\
\text { English. }\end{array}$ & 20 & 6 & 4 & \\
\hline 2 & $\begin{array}{l}\text { I am not confident to speak } \\
\text { English. }\end{array}$ & 24 & 6 & & \\
\hline 3 & $\begin{array}{l}\text { I am scared to speak English in } \\
\text { public. }\end{array}$ & 30 & & & \\
\hline 4 & $\begin{array}{l}\text { My friend always laughs when I } \\
\text { make mistakes. }\end{array}$ & 30 & & & \\
\hline 5 & I do not understand English. & 16 & 10 & 4 & \\
\hline 6 & $\begin{array}{l}\text { I cannot pronounce English } \\
\text { words. }\end{array}$ & 10 & 14 & 6 & \\
\hline 7 & $\begin{array}{l}\text { I am confused with some } \\
\text { words in English. }\end{array}$ & 14 & 10 & 6 & \\
\hline 8 & I do not like English. & 5 & & 5 & 20 \\
\hline 9 & $\begin{array}{l}\text { I am nervous to speak English } \\
\text { with my friend. }\end{array}$ & 20 & 5 & 5 & \\
\hline 10 & I am scared to use English. & 20 & 10 & & \\
\hline
\end{tabular}


From the result, we can see that the most picked questions are item number 3 and 4 . Most of the pupils are scared to speak in English and they become really nervous whenever they have to speak in public. They are also very shy because their friend usually laughs at them and this cause their motivation level to decrease. Peer pressure causes the pupils to become demotivated and also reluctant to speak in English.

The second item that cause anxiety is item 2, the pupils are not confident to speak in English. They know and able to communicate in English but they are not confident. This cause them to have language anxiety in speaking English.

The third most picked item are items 1, 9 and 10. Pupils were scared to speak in English even among their friends, probably it is because of their mind set itself. They are reluctant to communicate and also apply the language in everyday life.

The lowest picked item in the questionnaire is item number 8 . This shows that most of the pupils did not disfavour English. They like to acquire English; it is just that they are not assured to speak in English.

\section{Discussions}

The widely used of English language has demand the speakers to have good communication skills in using the language.

It is a general idea among learners that speaking is harder than other skills of learning English and it may be more important than other skills. Students tend to be more anxiety when they have to communicate with native speakers and also speaks without preparation. Their anxiety and insecurities cause them to become unable to utter their words in English.

Songs play an important role in early language development. Most people beliefs that to learn a language we must listen and speak the language. Young learners are usually more attracted to lesson that requires them to move actively and also sing along.

Songs are repetitive and by repeating the lyrics, pupils can learn new vocabulary and new language structures. It is important to choose songs that able to be enjoyed by children because it can give them the feeling of being forced to learn. Once they enjoy themselves, they will not feel demotivated. Likewise, from the interview and the responses from the pupils, we can see that they are enjoying themselves and pupils found the lessons amusing and they were learning something entertaining. For example, they learn how to pronounce certain new vocabulary, they become more confidence to use the new vocabulary when they are speaking in English.

Their confidence during the singing session also decreases their anxiety level. They are also more actively participating and more responsive when they are discussing and sharing opinion with their friends. Passive students also eventually and gradually began to respond actively. Cheng (1984) stated that the three language teaching techniques are via using games, sketches and songs.

\section{Conclusion}

In conclusion, the use of songs in the classroom will not only teach the students language but also expose them to real life issues that can be found in the lyrics of varieties of songs. The different genres of songs will also prolong their attention span and make them more attentive towards English lessons. Songs also can be easily memorized because of the fun melody and repetitive lyrics. Students 
tend to learn better with the use of songs and it will reduce their anxiety to speak in English language because they will be more confident in speaking the language. Therefore, the use of songs will increase pupils' motivation to speak English and reduce their anxiety of making mistakes while speaking English.

Language anxiety will reduce when using songs because songs effectively increases students' motivation and also interest in learning languages. They become more willing to learn and also participate in the activities that encourages them to communicate. This study concluded that the research participants become more active and shows massive interest in learning language after the implementation of song. Low proficiency students also show interest and increase in motivation. This shows that they are learning in a more fun and stress- free way. Further study should be conducted and implemented by using songs in other skills in teaching such as writing, listening and also reading.

\section{References}

Ary, Donald, Jacobs, Cheser, L., Sorensen, Chris, \& Razavieh, A. (2010). Introduction to Research in Education (8th ed.).

Al-Hazemi, H. (2000). Lexical Attrition of Some Arabic Speakers of English as a Foreign Language: a Study of Word Loss. Internet TESL J [Serial online] Available from: http://iteslj.org/Articles/AlHazemi-Attrition/

Al-Otaibi, G. (2004). Language Learning Strategy Use among Saudi EFL Students and Its Relationship to Language Proficiency Lever, Gender, and Motivation [PhD Dissertation]. Indiana (PA): Indiana University of Pennsylvania.

Beare, K. (2010) Music in the ESL classroom. http://esl.about.com/od/esleflteachingtechnique/a/brainmusic.html (May 25, 2011)

Cheng, W. (1984). Grammar Teaching in Perspective. CUHK Educational Journal, 12 (1), 78 - 87. Retrieved August 20, 2007 on the World Wide Web:

http://sunzi1.lib.hku.hk/hkjo/view/33/3300235.pdf

Lucas. R. I. (2010). A Study on Intrinsic Motivation Factors in Second Language Learning among Selected Freshman Students. The Philippine ESL Journal, 4, 6-23.

McNamara, C. (1999). General Guidelines for Conducting Interviews,

Authenticity Consulting, LLC, Retrieved from: http://www.managementhelp.org/evaluatn/intrview.htm

Murphey, T. (1990). The song stuck in my head phenomenon: a melodic DIN in the LAD? System 18, 53-64.

Orlova, N. F. (2003). Helping prospective EFL teachers learn how to use songs in conversation classroom. The internet TESL journal, 9.3. http://iteslj.org/Techniques/Orlova-Songs.html (August 1, 2011)

Ottilie. (2010) Is English compulsory course in your country? [Msg49] Message posted to http://forum.wordreference.com/showthread.php?t=1196978\&page=3 (July 24, 2011)

Peacock, M. (1997). The effect of authentic materials on the motivation of EFL learners. ELT journal, 51(2), 144-156.

Gilakjani, P. A., Leong, L. M., \& Saburi, N. B. (2012). Study on the Role of Motivation in Foreign Language Learning and Teaching. I.J. Modern Education and Computer Science, 7, 9-16. 
INTERNATIONAL JOURNAL OF ACADEMIC RESEARCH IN BUSINESS AND SOCIAL SCIENCES

Vol. 10, No. 2, Feb, 2020, E-ISSN: 2222-6990 @ 2020 HRMARS

Patton, M. Q. (2002). Qualitative Research and Evaluation Methods. (3rd ed.). United States of America: Sage.

Setia, R., Rahim, R. A., Nair, G. K. S., Mohd Adam, A. F. B., Husin, N., Sabapathy, E., Mohamad, R., Mat So'od, S. M., Md Yusoff, N. I., Razlan, M. R., Abd Jalil, N. A., Kassim, R. M., \& Abu Seman, N. (2012). English songs as means of aiding students' proficiency development. Asian Social Science, 8(7), 270-274

Suleimenova, Z. (2013). Speaking anxiety in a foreign language classroom in Kazakhstan. Procedia Social Behavioral Sciences 93, 1860-1868. https://doi.org/10.1016/j.sbspro.2013.10.131

Walker, R. (2006). Going for a song. I. English Teaching Professional (43), 19-21. 